\title{
塩化亜鉛水溶液を溶剤としたポリアクリロニトリル濃厚溶液の粘度安定性 ${ }^{* 1, * 2}$
}

(昭 和 41 年 3 月 22 日 受理)

中島通公*3

溶解法（D法）执よび溶液重合法（ $\mathrm{SP}$ 法）により， $\mathrm{ZnCl}_{2}-\mathrm{NaCl}$ 水溶液を溶剤とした，ポリフクリロニトリルの裖厚溶液を作 り，この溶液の粘度的性質を研究した。実験した範囲内では，ポリマー溶液の安定性について D 法, SP 法間の差異特よび分子量 の大小に基づく差異はあまり認められなかった。しかし塩水溶液中の全塩濃度 $\left(C_{\mathrm{t}}\right)$, 塩のモル比 $\mathrm{NaCl} / \mathrm{ZnCl} \mathrm{n}_{2}(=r)$, ならびにポ リマー組成が安定性に及ぼす影響は大で， $C_{\mathrm{t}}$ あるいは $1 / \boldsymbol{r}$ が小さいと溶剤のポリマー溶解力が少り，特にホモポリマーを溶かす 昜合にはゲル化が起こり易い。 $\mathrm{ZnCl}_{2}$ 濃度の高い塩水溶液を用いれば，ポリマ一濃厚溶液は安定であり，例えば $80^{\circ} \mathrm{C} て ゙ 5$ 時閒， あるいは室温で 15 日間放置しても，ポリマー溶液の粘度 $\left(V_{\mathrm{ps}}\right)$ ，その流動活性化ェネルギー $\left(\Delta E_{\eta}\right)$ はほとんど変わらない。この 範囲のポリマー濃厚溶液は DMF を溶版としたるのより高い $V_{\mathrm{ps}}, \Delta E_{\eta}$ を持つが，十分垁用的な紡系適性を持っている。 $V_{\mathrm{ps}}, \Delta E_{\eta}$ の值の高低に及ぼす $C_{\mathrm{t}}, r$ 扣よびポリマー組成の影響について考察した。

\section{1 緒言}

盐化覀鉛を主成分とする無機塩の濃厚水溶液を溶剤として，ポ リアクリロニトリルを主成分とするポリマーの溶液を製造するに は, ポリマーを溶解する方法と, モノマーを溶液重合する方法と の二通りの方法があることはよく知られている1。またそれぞれ の方法についての詳細は多数報告されている2 7)。

しかし実際の工業的紡系作業に適したポリマー濃度を有する溶 液について，繊維製造技術上から見て重要な意味を有するポリマ 一溶液の安定性といら問題については未だ報告はない。著者はこ の点に関連して, 各種組成の塩化亜鉛一塩化ナトリウム水溶液を 用いてポリマー溶液をつくり, その粘度, 流動活性化ェネルギー などの経時変化を測定し，興味ある結果を得たのでここに報告す る。

\section{2 実験}

\section{$2 \cdot 1$ 記号, 略号}

特に重要なるの，断りのないるのは既報 ${ }^{2 \sim 4), * 2}$ と同じである。

\section{$2 \cdot 2$ 実験法}

溶解法（D法と略記）の試料として用いたポリマーは $\eta_{\mathrm{sp}} / c=$ $2.34 * 4$ の $\mathrm{BASF}$ 社ポリアクリロニトリルと, $\eta_{\mathrm{sp}} / c=2.39 * 4$ の MA 8\% 含有の Bayer 社製コポリアクリロニトリルで, いずれも 未分別である。溶剤としては ZnO 含量 $0.075 \%$ の各種組成の塩 水溶液を用い, 溶解にはポリマー濃度 $9.1 \mathrm{wt} \%$ で, $120^{\circ} \mathrm{C}, 10$

*1この報文を「塩化覀鉛水溶液へのポリアクリロニトリルの 溶解 (第 8 報)」とする。

*2 前報(第 7 報), 中島通公, 工化, 70, 87 (1967).

*3 Michiaki NAKAJIMA 東邦レーヨン株式会社開発部：東 京都中央区日本橋通.

1）例えば片山, “アクリル系合成䋐維”, 日刊工業新聞社(1959).

2) 中島, 工化, $67,2133,2138$ (1964).

3) 中島, 三鍋, 工化, 68, 373 (1965).

4) 中島, 網屋, 工化, 68, 161 (1965).

5) 上田, 工化, 66, 252(1963) および東京工大学位論文 (1961).

6) 吉田, 高分子化学, 20,545, 550 (1963) および京都大学 工学部学位論交 (1961).

7）中島，日特公，昭 36-13087，その他

*4 $\eta_{\mathrm{sp}} / c$ の值は $\mathrm{DMF}$ を用い $30^{\circ} \mathrm{C}$ で, $c=0.5 \mathrm{~g} / 100 \mathrm{ml}$ で測 盗。Houtz 式による $\bar{M}$ はとれどれ 36300,37800 であ る。
分加熱を行なった。

溶液重合法（SP 法と略䛉）による溶液製造はつぎのようでめ る。溶剂には $\mathrm{ZnO}$ 含量 $0.05 \%$ の各種塩水溶液を用い, モノ、 一初濃度 $9.1 \%$ *5, 開始剂 APS 初濃度 $0.09 \% * 5$, 分子量調節剂 $\mathrm{Cu}^{2+} 0.6 \times 10^{-4} \% \%^{* 5}, 60^{\circ} \mathrm{C}, 180$ 分の加熱とい5.条件下で溶液重 合を行ない，重合率をほとんど 100\%に達せしめた。この方法で $A N$ 単独重合と, $A N: M A: A A=90: 7: 3$ (重量) の組成のモ ノマーによる共重合とを行なった。その他詳細は既報了)のと搞り である。

$V_{\mathrm{ps}}$ の測定法は従来と同じである2)。見掛けの流動活性化エネ ルギー $\Delta E_{\eta}$ は $30 \sim 80^{\circ} \mathrm{C}$ に和ける $V_{\mathrm{ps}}$ の温度依存性から常法に より算出した。测定に当っては，测定履歴炎のものによる誤差を 防ぐため, 製造したポリマー溶液を直後用, $80^{\circ} \mathrm{C}$ 放置用, 室温 放置用に分割し， $V_{\mathrm{ps}}$ については直後，途中，放置後の $50^{\circ} \mathrm{C}$ の 值をそれぞれ測定し，また $\Delta E_{\eta}$ については直後と放置後との值 を求めた。試料が不足したため, 途中の $\Delta E_{\eta}$ 求めることはでき なかった。放置後はかきまぜず単に静置した。

\section{3 結果と考察}

\section{$3 \cdot 1$ 粘度安定性}

図 1,2 拉よび表 1 にD法で作ったポリマー溶液の $V_{\mathrm{ps}}, \Delta E_{\eta}$ を，図 3，4 扎よび表 2 にP 法で作ったものの值を記した。表 中の $\log V_{\mathrm{s} 1}$ は前報*2で述べた意味に打ける塩水溶液のポリマー

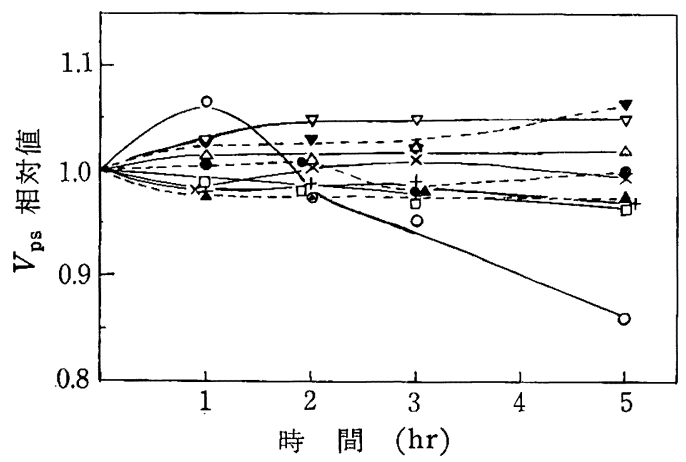

図 $180^{\circ} \mathrm{C}$ 放置の $V_{\mathrm{ps}}$ 変化（溶解法による.溶液） 实線はホモポリマーで, 十, $\times, \triangle, \square, \nabla, O$ の順に裴 1 买験番号 $(1) \sim(6)$ 点楾はコポリマーで,

*5この\%は全系（=モノマー+塩水溶液十開始剤など添加

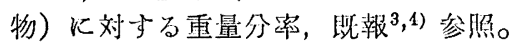


表 1 溶解法でつくったポリマー濃厚溶液の粘度の経時変化

\begin{tabular}{|c|c|c|c|c|c|c|c|c|c|c|}
\hline \multirow{2}{*}{ 尖験䧽号 } & \multicolumn{3}{|c|}{ 溶＼cjkstart唁 } & \multirow{2}{*}{ ポリマー稞別 } & \multicolumn{3}{|c|}{$V_{\mathrm{ps}}$ ポイズ $\left(50^{\circ} \mathrm{C}\right)$} & \multicolumn{3}{|c|}{$\Delta E_{\eta}(\mathrm{kcal} / \mathrm{mol})$} \\
\hline & $c_{\mathrm{t}}$ & $r$ & $\log V_{\mathrm{sI}}$ & & $l$ & $m$ & $n$ & $l$ & $m$ & $n$ \\
\hline (1) & 60 & 0 & 5.3 & ホモポリマー & 280 & $0.97_{3}$ & 0.96 & 8.80 & 1.00 & $1.00_{1}$ \\
\hline (2) & 58 & " & 3.8 & " & 240 & $0.99_{6}$ & $0.94_{3}$ & 8.64 & $1.01_{B}$ & 1.00 \\
\hline (3) & $"$ & 0.55 & 3.1 & " & 138 & $1.01_{8}$ & 1.04 & 8.09 & 1.00 & $1.03_{2}$ \\
\hline (38) & $" 1$ & " & "I & コポリマー & 137 & $0.97_{5}$ & $0.92_{7}$ & 7.55 & 1.10 & 1.05 \\
\hline (4) & " & 1.14 & 2.3 & ホモポリマー & 93 & $0.96_{8}$ & $0.95_{1}$ & 7.52 & 1.00 & 1.00 \\
\hline (6) & 56 & 0.25 & $2.1_{5}$ & " & $587^{\mathrm{a}}$ & 0.86 & $\begin{array}{l}50^{\circ} \mathrm{C} \text { 以下では } \\
\text { ゲルした。 } \\
\text { のため測れす }\end{array}$ & $>10 \mathrm{~b}$ & $>10^{b}$ & $\begin{array}{l}\text { ゲル化し } \\
\text { て測れず }\end{array}$ \\
\hline (68) & $"$ & $"$ & $"$ & コポリマー & 122.5 & 0.99 & $0.94_{7}$ & 8.08 & 1.00 & $0.95_{7}$ \\
\hline (5) & 55 & 0 & $2.0_{5}$ & ホモポリマー & $199^{\mathrm{a}}$ & 1.05 & 1.84 & 8.35 & 1.00 & $1.29_{2}$ \\
\hline (58) & $"$ & " & $"$ & コポリマー & 98.5 & $1.06_{4}$ & $0.99_{1}$ & 8.06 & 1.00 & 0.98 \\
\hline
\end{tabular}

$\log V_{\mathrm{sI}}$ : 前報の図 1，3 から求めた， $a:$ 不透明でゲルに近い, $b: V_{\mathrm{ps}} \sim 1 / T$ が直線関保を示さず低温で異常に

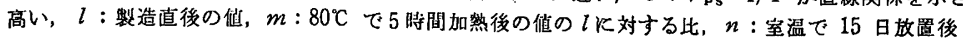

表 2 溶液集合法でつくったポリマー濃厚溶液の粘度の経時変化

\begin{tabular}{|c|c|c|c|c|c|c|c|c|c|c|c|}
\hline \multirow{2}{*}{ 实略番号 } & \multicolumn{3}{|c|}{ 溶_剂 } & \multicolumn{2}{|c|}{ ポリマー } & \multicolumn{3}{|c|}{$V_{\mathrm{ps}}$ ポイズ $\left(50^{\circ} \mathrm{C}\right)$} & \multicolumn{3}{|c|}{$\Delta E_{\eta}(\mathrm{kcal} / \mathrm{mol})$} \\
\hline & $C_{\mathrm{t}}$ & $r$ & $\log V_{\text {sI }}$ & 别 & $\overline{\eta_{\mathrm{sp}} / c}$ & $l$ & $m$ & $n$ & $l$ & $m$ & $n$ \\
\hline (110) & 60 & 0 & 5.6 & ホモポリマー & 1.86 & 138 & $0.98_{1}$ & $0.93_{3}$ & 8.62 & $0.96_{5}$ & $0.94_{2}$ \\
\hline (120) & 58 & "I & 3.9 & "I & 2.00 & 106 & 1.02 & 0.90 & 8.58 & $1.01_{8}$ & 1.00 \\
\hline (130) & $" 1$ & 0.55 & 3.2 & " & 1.93 & 82 & $1.0 \mathrm{I}_{5}$ & 1.00 & 7.78 & 1.00 & $0.99_{1}$ \\
\hline (138) & " & " & " & コポリマー & 1.61 & 42 & $0.97_{\mathrm{B}}$ & $0.92_{5}$ & 7.65 & 1.00 & 1.00 \\
\hline$(140)$ & $"$ & 1.14 & $2.3_{5}$ & ホモポリマー & 1.73 & 51 & $1.03_{7}$ & 1.01 & 7.36 & $1.02_{8}$ & $1.00_{2}$ \\
\hline$(160)$ & 56 & 0.25 & 2.2 & " & 2.79 & $793^{a}$ & 測定 & 不能 & 測 & 定 不 & 能 \\
\hline (168) & $"$ & " & " & コポリマー & 2.12 & 101 & $0.94_{3}$ & $0.87_{1}$ & 8.15 & 1.05 & $1.00_{\mathrm{B}}$ \\
\hline (150) & 55 & 0 & 2.1 & ホモポリマー & 2.77 & 測 & 定 不 & 能 & 測 & 定 不 & 能 \\
\hline (158) & $"$ & " & " & コポリマー & 1.75 & 37 & $0.94_{8}$ & $0.87_{2}$ & 8.13 & 1.00 & 1.00 \\
\hline
\end{tabular}

$\log V_{\text {sI }}, a, l, m, n:$ 表 1 K间じ

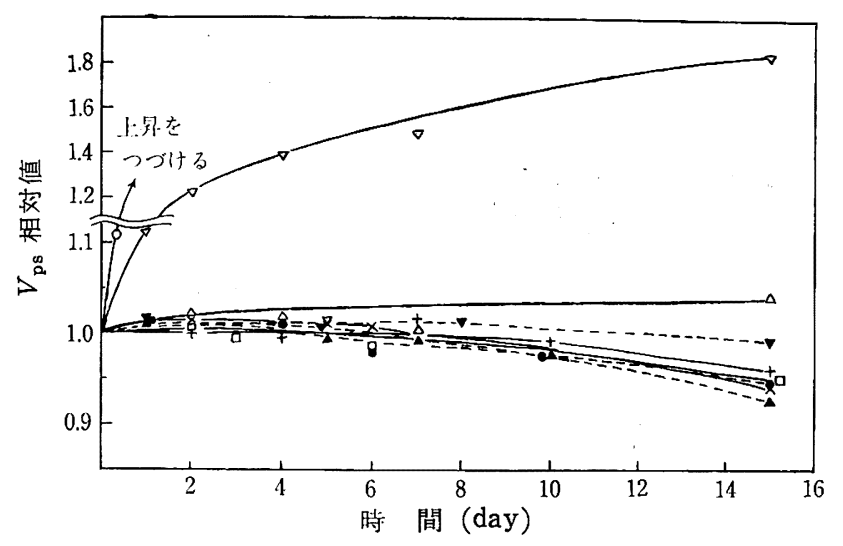

図 2 室温放厧の $V_{\mathrm{ps}}$ 変化（溶解法による溶液） 萼号は因1 K同じ

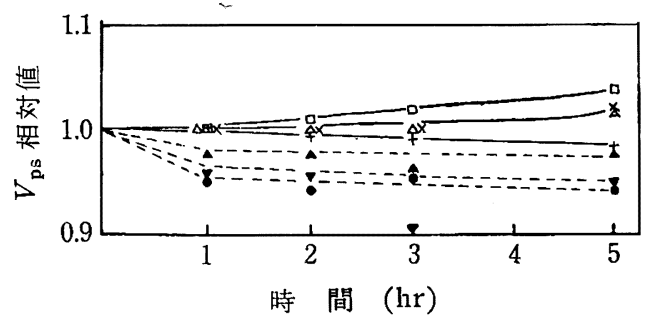

因 $380^{\circ} \mathrm{C}$ 放置の $V_{\mathrm{ps}}$ 変化（溶液重合法に上る溶液）

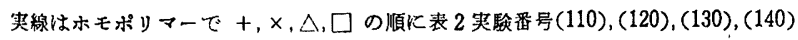
点線はコポリマーでム、 、，の順に (138), (158), (168)

溶解力を示す尺度として, 前報記載から求めたものである。

3.1.1 $V_{\mathrm{ps}}$ から見た粘度安定性 D法, SP 法とも製造直後に 抽いてすでにゲル化している No. 5，6，150，160 のホモポリマ 一溶液以外は， $V_{\mathrm{ps}}$ の経時変化が小さくて，安定性の良いことを 示している。No.58 (D法, コポリマー), No.140 (SP 法, 小モ ポリマー) のよ $5 K, 80^{\circ} \mathrm{C}$ 放置で $V_{\mathrm{ps}}$ がやや上昇しているのは, 溶液の肉眼的透明度がよくなったことが認められるので, ゲル組
織の新たな発生と考えるよりむしろ加熱 により不完全溶解状態から完全溶解状態 に移行したことによるものと考えられ る。また No. 158, 168 (いずれる SP 法, コポリマー) の上5に, 放置により $V_{\mathrm{ps}}$ がいくらか低下するむのもある。こ れは最初存在していたゲル組織（肉眼で は明瞭には白濁とか，不透明は認められ ない）が，放置の間に破壊されたことを 示すものと考えられる*6。

3.1.2 $\Delta E_{\eta}$ から見た粘度安定性 $\Delta E_{\eta}$ の経時変化は $V_{\mathrm{ps}}$ のそれと平行的であ って, 初めからゲル化している No. 5, $6,150,160$ を除いては変動が小さい。 すなわち安定であるといえよう。

\subsection{D法之 SP 法との差異}

上述の結果からわかるように, $V_{\mathrm{sp}}$. $\Delta E_{\eta}$ の経時変化から見ると, 粘度安定性 については，D法と SP 法との間に差異 はないようである。しかし $V_{\mathrm{ps}}, \Delta E_{\eta}$ の 値そのものにはかなりの違いがある。実

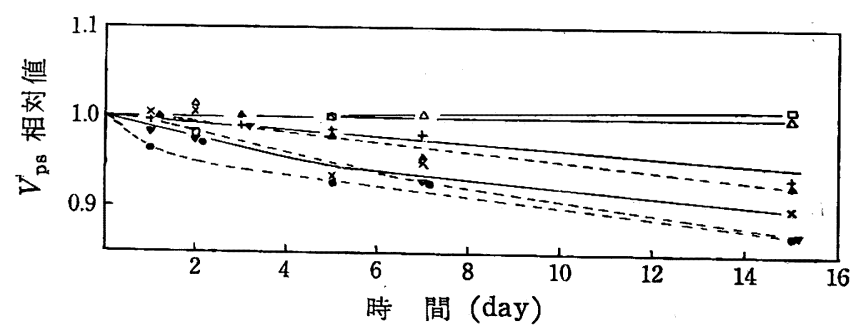

図 4 室温放置の $V_{\mathrm{ps}}$ 変化（溶液重合法による溶液） 記号は图3K同し

験試料を作るときには，このような差異が生じないようにそれぞ れの製造条件を選んだわけで，D法と SP 法とが対応するよう， 溶解力のほとんど等しい溶剤（表 $1 ， 2$ の $\log V_{\mathrm{B} 1}$ 参照）を用い たり，D 法のコポリマーが加熱変質によって少量の AA 成分を 生じること2)を考慮に入れて, SP 法の共重合モノマー組成を决 めたりした。

しかし SP 法のものは, ポリマー濃度が敩密には $9.1 \%$ に達 していないし，それに相当する量だけ未反応のモノマーを含んで いる。また分子量に関しては, 使用した塩水溶夜の性状 $\left(C_{t}, r\right.$, ZnO 含量）によって重合反応の挙動が非常に異なるので8), 表 2 に記したよ5に，分子量はまったく一定してない結果を与えてい る。このようなことが $\mathrm{SP}$ 法の $V_{\mathrm{ps}}, \Delta E_{\eta}$ の值を対応する $\mathrm{D}$ 法 のものと異ならしめたものと考えられる。

また SP 法のコポリマー溶液 No. 138，158，168などは，対 㐫する $\mathrm{D}$ 法のものより $\eta_{\mathrm{sp}} / c$ が小さくて， $V_{\mathrm{ps}}$ む小さいにもかか わらず, $\Delta E_{\eta}$ は大である。これは $\mathrm{SP}$ 法のすのが $\mathrm{D}$ 法のすのよ り, 製造直後にあっては, ポリマーの溶解状態が悪いことを示す ものと思われる。 D 法では $120^{\circ} \mathrm{C}$ の加熱溶解を行なっているか ら，溶剂中へのポリマーの分散がょく進んでいるのに反し，SP法

\footnotetext{
*6 ゲル構造が放置により破壊されることについては著者らの 観測がある。中島, 須加井, 山腰 (東邦レ) 未発表。

8）著者, 未発表.
} 
ではポリマーの非溶剤であるモノマーをいくらか含んでいること も影響しているょ5である。

\section{$3 \cdot 3$ 塩水溶液の組成ならびにポリマー組成の影響}

今まで述べたように, $V_{\mathrm{p} 6}, \Delta E_{\eta}$ の值の大小には $\mathrm{SP}$ 法, D汒 といら製造方法そのものの違いよりも，ポリマー組成の差買，分 子量の大小の方が影響していると同時に, 塩水溶液の組成のちが いKよるポリマー溶解力の大小（ $V_{\mathrm{B} 1}$ 值の大小）も強い影響をも っていることが，表 1，2 からわかる。またポりマー溶液の安定 性には，特に溶剂組成の影響が大きいことが示されている。

$\mathrm{ZnCl}_{2}$ 濃度（wt\% で表示して）の高い濃厚水溶液に $\mathrm{H}_{2} \mathrm{O}$ あ るいは $\mathrm{NaCl}$ を加えて相対的に $\mathrm{ZnCl}_{2}$ 濃度を下げていくと，ポ リマー溶解力が小さくなる $\left(V_{\mathrm{s} 1}\right.$ 大 $\rightarrow$ 小) ことは, 前報*2に述べ た。溶剤の組成変化に基づく溶解力の変化が $V_{\mathrm{ps}}, \Delta E_{\eta}$, ゲル構 造発生の難易に影響を与えることは，DMSO，DMF などの有機 溶媒を用いた溶夜においてすで種々明らかにされている

上記の $\mathrm{ZnCl}_{2}-\mathrm{NaCl}-\mathrm{H}_{2} \mathrm{O}$ 系のポリマー溶液にに関する挙動む， それら有機溶媒系に抽ける現象と対比して見ると，特に異なった ものではないことがわかる。ただし放置の際, 変質による分子量 低下²が若干起こると思われるが， $V_{\mathrm{ps}}$ 低下率最大（ただし No. 6 以外で）の No. 38 室温放置物でも，分子量の低下率はたかだ か $2 \%$ 弱であって，分子量はほとんど不変と見てよい程度である。

また表 1,2 の結果から, 実験した範囲では, $\log V_{\mathrm{sl}} \leqq 2.2$ を 示す塩水溶液中で, コポリマーは溶液として安定であるに対し， ホモポリマーはゲル化することが明らかである。この $V_{\mathrm{s} 1}$ 值は: ポリマーに対する実際上の溶解についての下限となっている $C_{\mathrm{t}}{ }^{* 2}$ よりも少し高い $C_{\mathrm{t}}$ に相当することを示していて，コポリマーよ り溶解性の劣るホモポリマーに対する実際上の溶解下限塩濃度は この近傍にあるといえよう*7。

9) 高灀, a ) 高分子化学, 16, 35 (1959), 高分子化学, 19, $16,235(1962) ;$ b ) 絨学誌, 16,628 (1960).

10) 片山, 交献 1) の p. 182 .

11) 宮道, 高分子化学, $17,672,675$ (1960).

*7 溶解の下限塩濃度がポリマーの種類によって变わることは Hunyar も報じている。Faserforsch. Textiltech., 6, 496 (1955).
4 総括

以上述ヘたように，D法，SP 法のいずれにせよ递当な浴解力 $\left(\log V_{\mathrm{s} 1}>2.2\right)$ 苍掠つ $\mathrm{ZnCl}_{2} \mathrm{NaCl}$ 水溶液を用いれば，粘度的に 定定なポリマー溶液が得られることがわかった。ここに得たポリ マ一浴液を有機浴媒系のものと比侪刘照して特徵をはっきりさせ て見たのがつぎの表 3 である。対照には DMF 系について高憍㥸， 柚口12)らが報告したものを用いた。

表 3 溶媒によるポリマー溶液性状の差異

\begin{tabular}{|c|c|c|}
\hline & $\mathrm{DMF}$ & 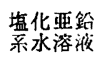 \\
\hline 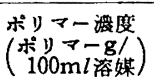 & $14 \sim 20$ & $15 \sim 19$ \\
\hline$V_{\mathrm{ps}}$ & $60 \sim 250$ & $\begin{array}{c}40 \sim 300 \\
7 \sim 9\end{array}$ \\
\hline $\begin{array}{c}\Delta E_{\eta} \\
\text { 炶度安定性 }\end{array}$ & $\begin{array}{c}3 \sim 6 \\
\text { 良 }\end{array}$ & $\begin{array}{l}\text { 舟 } \\
\text { 良 }\end{array}$ \\
\hline
\end{tabular}

このよ5に塩化亜鉛水溶液の場合， $V_{\mathrm{ps}}, \Delta E_{\eta}$ が喬いことが特 徵であるといえる。極限粘度 [ $\eta$ ] の大小から判定された良溶郕 順位*8，60\% $\mathrm{ZnCl}_{2}>\mathrm{DMSO}>\mathrm{DMF}$ において，その筆頭である 塩化亜鉛水溶液が濃厚ポリマー溶液の $V_{\mathrm{ps}}, \Delta E_{\eta}$ とも高い值を示 していることは, DMSO と DMF との比較について 述べられた 傾向 ${ }^{9 \sim 11)}$ と一致している。

そして表 3 の範囲の塩化亜鉛系水溶液を溶剂とするポリマー濃 厚溶液はD法, SP 法ともに無色ないし淡黄緑色の透明流体であ り，凝固性 ${ }^{2)}$ む非常に良く，紡系原液としてすぐれた実用価値を 持っている。

終りに臨み，御意見を睗わった東京大学教授岩倉義男博士に厚 く感謝します。また発表を許可された会社当局に深謝します。

12) 柚口, 高分子化学, 19, 113 (1962).

*8 宮道 ${ }^{11)}$ によると $[\eta]$ の大小は $60 \% \mathrm{ZnCl}_{2}>\mathrm{DMSO}>\mathrm{DMF}$ であって, $60 \% \mathrm{ZnCl}_{2}$ が，この中では最も良い溶剤であ るという。 